\title{
Effects of dietary vitamin $E$ on growth performance as well as intestinal structure and function of channel catfish (Ictalurus punctatus, Rafinesque 1818)
}

\author{
MIN HE, KAIYU WANG, XIAOXIA LIANG, JING FANG, YI GENG, \\ ZHENGLI CHEN, HAIBO PU, YAODONG HU, XUE LI and LING LIU \\ Key Laboratory of Animal Disease and Human Health of Sichuan, Animal's Medical College, \\ Sichuan Agricultural University, Chengdu, Sichuan 625014, P.R. China
}

Received March 18, 2016; Accepted February 24, 2017

DOI: $10.3892 /$ etm.2017.5295

\begin{abstract}
To evaluate the impact of dietary vitamin E supplementation on growth performance, the intestinal structure and function of channel catfish (Ictalurus punctatus, Rafinesque 1818) was investigated. A total of 900 healthy channel catfish (weight, $5.20 \pm 0.15 \mathrm{~g}$ ) were divided into four groups, which received experimental diets with different vitamin $E$ content $(0,50,100$ or $1,000 \mathrm{mg} / \mathrm{kg})$. At the end of the feeding trial (after 15 weeks), the growth and gut performance of the animals was determined. The digestive enzyme activity in hepatopancreas and gut was also detected. In addition, the height of intestinal fold, the thickness of the mucous membrane and the number of somatostatin-positive cells was examined by histological analysis. Dietary vitamin E supplementation at 50 and $100 \mathrm{mg} / \mathrm{kg}$ significantly improved the growth and gut performance, which also increased the activity of several digestive enzymes compared to that in animals without vitamin $\mathrm{E}$ supplementation $(\mathrm{P}<0.05)$. In addition, vitamin $\mathrm{E}$ supplementation also significantly increased the height of intestinal fold and the thickness of the mucous membrane $(\mathrm{P}<0.05)$. Fish with dietary vitamin $\mathrm{E}$ supplementation at appropriate doses also had more somatostatin-positive cells in than those without vitamin $\mathrm{E}$ supplementation $(\mathrm{P}<0.05)$. In conclusion, dietary vitamin E supplementation at 50 and $100 \mathrm{mg} / \mathrm{kg}$ was shown to improve the growth performance as well as intestinal structure and function of channel catfish.
\end{abstract}

Correspondence to: Dr Min He, Key Laboratory of Animal Disease and Human Health of Sichuan, Animal's Medical College, Sichuan Agricultural University, 211 Huimin Road, Chengdu, Sichuan 625014, P.R. China

E-mail: minheter3@163.com

Key words: vitamin E, intestine structure and function, growth performance, gastrointestinal tract, channel catfish

\section{Introduction}

Vitamin $\mathrm{E}$ is a generic term for all naturally occurring tocopherols and tocotrienol as well as their derivatives (1). This fat-soluble vitamin was discovered and named by Evans in the 1920s $(2,3)$. Since its hydroxyl moiety on carbon 6 can be easily oxidized, vitamin $\mathrm{E}$ has a strong reducibility, which protects important substances from oxidation in vivo and has an important role in the maintenance of normal metabolic processes and physiological function in the body (4). Vitamin E is required to protect the cell membrane from peroxide damage, maintain immunity and enhance resistance to disease, whilst it is tightly associated with embryonic development, nucleic acid metabolism, ascorbic acid biosynthesis as well as maintenance of tissue quality (5-9). Vitamin $\mathrm{E}$ has become one of the most important vitamins in aquatic animal breeding. A large number of studies have reported that vitamin E deficiency impairs aquatic animal performance, including a reduced weight gain, protein efficiency ratio as well as feed coefficient (10-15).

The channel catfish (Ictalurus punctatus, Rafinesque 1818) is well known for its meat that is tasty and high in amino acids. It is naturally distributed within the USA and Canada and has been widely introduced to other countries worldwide due to its value (16). This fish has become one of the most economically important fish in China. Channel catfish require relatively high levels of vitamin $\mathrm{E}$ and its deficiency significantly inhibits fish growth (17). The intestine is a major organ for energy and nutrition absorption to maintain survival, growth and reproduction of fish. Although several studies have investigated the effects of vitamin $\mathrm{E}$ on weight gain, tissue ascorbate concentration as well as stress responses (18-20), few studies have investigated the effects of vitamin $\mathrm{E}$ on the intestinal structure and function.

The first purpose of the present study was to investigate the effect of vitamin E supplementation on growth performance and to determine the optimum dietary vitamin E supplementation level for channel catfish. The second purpose of the study was to explore the effects of vitamin E supplementation on the intestinal structure and function of channel catfish. In addition, the present study assessed the effects of vitamin $\mathrm{E}$ supplementation on the expression of somatostatin, which is 
distributed in the gastrointestinal tract and acts as a hormone as well as a neurotransmitter to regulate a variety of physiological processes, such as the body's growth, development and metabolism (21-23). The present study provided a scientific reference for the breeding of channel catfish.

\section{Materials and methods}

Experimental diets. All experimental protocols were approved by the University of Sichuan Agricultural Animal Care Advisory Committee (Ya'an, China). The experimental diets were varied with regard to the level of vitamin $\mathrm{E}$. The basal diet (Table I) was formulated according to the Nutrient Requirements of Fish from the NRC National Research Council (24) and was supplemented with 0, 50, 100 or $1,000 \mathrm{mg} / \mathrm{kg}$ Dl-all-rac- $\alpha$-tocopherol acetate (Sanyou Institute of Special Additives, Chengdu, China). A study utilizing the dose of $1,000 \mathrm{mg} / \mathrm{kg}$ has been described previously (25). For diet preparation, the ingredients were ground into fine powder and screened through a mesh $(0.38 \mathrm{~mm})$. All ingredients were then thoroughly mixed and made into a $4 \mathrm{~mm}$-diameter soft pellet diet using a pellet feed mill. After natural air drying in the dark, the pellets were preserved in a freezer at $-20^{\circ} \mathrm{C}$. In addition, to assess the proximate composition of the diets, crude protein, crude fat and energy were determined using a Kjeldahl apparatus (nitrogen x6.25; Xi'an HEB Biotechnology Co., Ltd., Xi'an, China), extraction with petroleum ether by a Soxhlet apparatus (Xi'an HEB Biotechnology Co., Ltd.) followed by ash incineration at $600^{\circ} \mathrm{C}$ for $3 \mathrm{~h}$ and bomb calorimetry, respectively. The composition of the catfish's diet is shown in Table I.

Experimental animals. A total of 900 healthy channel catfish

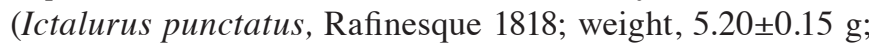
age, 2 years old) were purchased from a fish farm (Sichuan Fisheries Science and Technology Development Co., Ltd., Xinjin, China), where they were originally hatched and reared. They were randomly divided into four groups (225 fish per group) according to the vitamin E content in the experimental diet. For each group, fish were equally divided among three circular tanks with a volume of 201 (total number of tanks, 12), leading to a density of 75 fish per tank.

Prior to starting the feeding trial, fish were acclimatized for two weeks on a basal diet that was not supplemented with vitamin $\mathrm{E}$ and then fed one of the four experimental diets by hand three times daily $(07: 30,13: 30$ and 19:30 h) to approximate satiation for 15 weeks based on percentage body weight. Feed consumption was monitored at each feeding. The feeding rate was adjusted once or twice a week based on the feeding activity of fish. The tanks were configured as a flow-through culture system and the incoming water was filtered with aeration. The average water temperature was $21 \pm 2^{\circ} \mathrm{C}$ with a $\mathrm{pH}$ of 6.8-7.5, and the amount of dissolved oxygen was $8-10 \mathrm{mg} / \mathrm{l}$. Fish were reared in a $12 \mathrm{~h}$ light/dark cycle.

Growth performance. All of the fish in each tank were counted and weighed to monitor growth rates at the end of the feeding trial. The parameters indicating the growth performance of catfish in each group, including average weight gain, average daily growth, feed coefficient and protein efficiency ratio,
Table I. Composition of the basal diet of the catfish.

Ingredients and proximate composition

Amount

Ingredients ( $\mathrm{g} / \mathrm{kg}$ dry weight)

Gelatin

Fish meal

Rice protein concentrate

Soybean meal

23.68

$\alpha-$ Starch

32.77

$\mathrm{CaH}_{2} \mathrm{O}_{4}$

0.8

Chlorocholine

0.4

Ethoxyquin

0.05

Vitamin mixture (vitamin E-free)

0.1

Mineral mixture ${ }^{\mathrm{b}}$

1

Soybean oil

1

Fish oil

Proximate composition (\%)

Crude protein

Crude fat

Ash

Available phosphorus

0.45

Vitamin E (mg/kg)

2.09

Gross energy $(\mathrm{MJ} / \mathrm{kg})^{\mathrm{c}}$

${ }^{\mathrm{a}}$ Vitamin premix (IU/kg): $\mathrm{V}_{\mathrm{a}}, 4,400 ; \mathrm{V}_{\mathrm{d} 3}, 2,200 ; \mathrm{V}_{\mathrm{k}}, 44 ; \mathrm{V}_{\mathrm{B} 1}, 11$; $\mathrm{V}_{\mathrm{B} 2}, 13.2 ; \mathrm{V}_{\mathrm{B} 6}, 11 ; \mathrm{V}_{\mathrm{B} 12}, 0.01 ; \mathrm{V}_{\mathrm{H}}, 0.5 ;$ pantothenate, 35.2; $\mathrm{V}_{\mathrm{PP}}, 88$; pteroyltriglutamic acid, 22; becholine, $275 ; \mathrm{V}_{\mathrm{c}}, 40 .{ }^{\mathrm{b}}$ Mineral premix (IU/kg): $\mathrm{FeSO}_{4} \mathrm{xH}_{2} \mathrm{O}, 400 ; \mathrm{ZnSO}_{4} \mathrm{xH}_{2} \mathrm{O}, 350 ; \mathrm{CuSO}_{4} \times 5 \mathrm{H}_{2} \mathrm{O}, 450$; $\mathrm{MnSO}_{4} \mathrm{xH}_{2} \mathrm{O}, 420 ; \mathrm{KI}, 460 ; \mathrm{Na}_{2} \mathrm{SeO}_{4}, 520 ; \mathrm{KCl}, 550 ; \mathrm{NaCl}, 650$. ${ }^{\mathrm{c}}$ Gross energy = protein $(23.9 \mathrm{~kJ} / \mathrm{g})+\operatorname{lipid}(39.8 \mathrm{~kJ} / \mathrm{g})+$ carbohydrate $(17.6 \mathrm{~kJ} / \mathrm{g}) . \mathrm{V}$, vitamin.

were calculated following standard protocols. The formulas were as follows: i) Average weight gain (g/fish) = average final weight (g) - average initial weight (g); ii) Average daily growth ( $\mathrm{g} / \mathrm{fish} /$ day $)=$ average weight gain $(\mathrm{g} / \mathrm{fish}) /$ duration of experiment (days); iii) Protein efficiency ratio $=$ wet weight gain $(\mathrm{g}) /$ protein intake $(\mathrm{g})$; iv) Feed coefficient $(\%)=$ dry feed fed $(\mathrm{g}) /$ wet weight gain $(\mathrm{g})$; and v) Survival $(\%)=$ (final number of fish/initial number of fish) x $100 \%$.

Analysis of digestive enzyme in hepatopancreas and gut. After recording of body measurements, 45 fish were collected from each group. The hepatopancreas and gut of fish were removed, frozen in liquid nitrogen and then preserved at $-80^{\circ} \mathrm{C}$ for further analysis. For digestive enzyme analyses, tissue samples were homogenized in ice-cold physiological saline and the supernatant was retained after centrifugation at 3,200 x g for $20 \mathrm{~min}$. The activities of lipase were evaluated using phenolphthalein indicator and the activities of protease were determined by the Folin-phenol reagent method. In addition, the alkaline phosphatase (AKP) assay kit (Nanjing Jiancheng, Nanjing, Jiangsu, China) were used to evaluate the AKP activities, and $\mathrm{Na}^{+} / \mathrm{K}^{+}$-ATPase activities were assessed using a $\mathrm{Na}^{+} / \mathrm{K}^{+}$-ATPase assay kit (Nanjing Jiancheng, Nanjing, China). 
Table II. Effects of dietary supplementation of vitamin E on growth performance of channel catfish (Ictalurus punctatus, Rafinesque 1818).

Vitamin E supplementation (mg/kg)

\begin{tabular}{lrcrr}
\cline { 2 - 4 } Variable & \multicolumn{1}{c}{0} & 50 & 100 & 1,000 \\
\hline Initial weight $(\mathrm{g})$ & $5.21 \pm 0.08$ & $5.22 \pm 0.09$ & $5.20 \pm 0.06$ & $5.19 \pm 0.11$ \\
Final weight $(\mathrm{g})$ & $62.93 \pm 2.36$ & $76.10 \pm 1.43^{\mathrm{a}}$ & $77.20 \pm 2.38^{\mathrm{a}}$ & $73.93 \pm 0.37^{\mathrm{a}}$ \\
Average weight gain (g/fish) & $57.73 \pm 2.55$ & $70.41 \pm 2.93^{\mathrm{a}}$ & $72.00 \pm 2.74^{\mathrm{a}}$ & $69.75 \pm 0.64^{\mathrm{a}}$ \\
Average daily growth (g/fish/day) & $2.61 \pm 0.03$ & $2.96 \pm 0.06^{\mathrm{a}, \mathrm{b}}$ & $2.99 \pm 0.50^{\mathrm{a}, \mathrm{b}}$ & $2.85 \pm 0.02^{\mathrm{a}}$ \\
Protein efficiency ratio & $1.39 \pm 0.08$ & $1.63 \pm 0.03^{\mathrm{a}}$ & $1.63 \pm 0.06^{\mathrm{a}}$ & $1.53 \pm 0.02^{\mathrm{a}}$ \\
Feed coefficient (\%) & $2.06 \pm 0.12$ & $1.75 \pm 0.03^{\mathrm{a}, \mathrm{b}}$ & $1.74 \pm 0.06^{\mathrm{a}, \mathrm{b}}$ & $1.95 \pm 0.02$ \\
Survival (\%) & $70.56 \pm 4.19$ & $97.22 \pm 2.55$ & $97.78 \pm 0.96$ & $96.34 \pm 3.85$
\end{tabular}

Values are expressed as the mean \pm standard deviation. ${ }^{\mathrm{a}} \mathrm{P}<0.05$, compared to the group receiving $0 \mathrm{mg} / \mathrm{kg}$ vitamin $\mathrm{E}$; ${ }^{\mathrm{b}} \mathrm{P}<0.05$, compared to the group receiving $1,000 \mathrm{mg} / \mathrm{kg}$ vitamin $\mathrm{E}$.

Gut performance. Another 45 fish collected from each group at the end of the feeding trial were dissected and the guts were removed. The gut weight and length of the fish from each group was recorded. Moreover, the gut weight index and gut length index were calculated as follows: i) Gut weight index $(\%)=$ average gut weight $(\mathrm{g}) /$ average final body weight (g)] x 100\%; and ii) Gut length index $(\%)=$ [average gut length (cm)/average final body length (cm)] x $100 \%$.

Histological analysis. After recording of body measurements, another 20 fish were collected from each group and $0.5 \mathrm{~cm}$ of each segment of intestine was sampled on a chilled cutting board according to a previous description (26). Samples were fixed in Bouin solution for $12 \mathrm{~h}$, embedded in paraffin (Sigma-Aldrich, Merck KGaA, Darmstadt, Germany) and cut into 5- $\mu \mathrm{m}$ sections using a Leica RM2128 microtome (Leica Microsystems, Wetzlar, Germany). A proportion of the sections from each segment of the intestine was stained with hematoxylin and eosin (H\&E) and observed under an Olympus BH-2 microscope (Olympus, Tokyo, Japan). The height of intestinal folds and the thickness of the mucous membrane were evaluated by analyzing more than ten different views of each sample of intestine segment using Spot software (Version 4.0.6; Diagnostic Instruments, Sterling Heights, MI, USA).

The other part of the tissue sections was used for immunohistochemical analysis for detecting the distribution and expression of somatostatin. After washing with PBS three times, sections were rehydrated and incubated in $3 \% \mathrm{H}_{2} \mathrm{O}_{2}$ for $10 \mathrm{~min}$. Subsequently, sections were incubated with rabbit anti-somatostatin primary antibody (BA0124; Wuhan Boster Biological Technology, Ltd, Wuhan, Hubei, China) at a dilution of $1: 100$ at $4^{\circ} \mathrm{C}$ for $17 \mathrm{~h}$, followed by incubation with the biotin-conjugated goat anti-rabbit secondary antibody (BA1003; Wuhan Boster Biological Technology, Ltd, Wuhan, Hubei, China). Finally, sections were stained using a Streptavidin-Biotin Peroxidase Complex kit (Wuhan Boster Biological Technology, Ltd, Wuhan, Hubei, China) and visualized using diaminobenzidine as a chromogen. Sections incubated with PBS instead of primary antibody were considered as a negative control. The slices were observed and images were captured using a digital camera (Moticam 2500, Motic, Hong Kong, China) attached to a Nikon microscope (Nikon Eclipse 50i, Nikon, Tokyo, Japan). The expression of somatostatin among groups was evaluated by determining the number of somatostatin-positive cells. Ten different views per section of each segment of intestine (three sections for each segment intestine from each group) were obtained to analyze the expression and distribution of somatostatin.

Statistical analysis. Values are expressed as the mean \pm standard deviation. Significant differences among groups were determined by one-way analysis of variance followed by Duncan's method. $\mathrm{P}<0.05$ was considered to indicate a statistically significant difference between groups. All statistical analyses were performed with SPSS 19.0 software (International Business Machines, Inc., Armonk, NY, USA).

\section{Results}

Effect of vitamin E supplementation on the growth performance of channel catfish. Average weight gain, protein efficiency ratio, feed coefficient as well as survival were calculated and presented in Table II. Dietary supplementation with vitamin $\mathrm{E}$ affected catfish survival and fish with vitamin E supplementation at different concentrations showed a higher survival rate than those without. In addition, the fish receiving diets supplemented with vitamin E had significantly higher growth parameters, including average weight gain, average daily growth as well as protein efficiency ratio than those fed with the basal diet $(\mathrm{P}<0.05)$ and the highest values occurred in fish receiving a diet supplemented with vitamin $\mathrm{E}$ at $100 \mathrm{mg} / \mathrm{kg}$. The feed coefficient is used to evaluate the feed quality with a lower the feed coefficient indicating a higher feed quality. As shown in Table II, dietary supplementation with 50 and $100 \mathrm{mg} / \mathrm{kg}$ vitamin E had an obviously lower feed coefficient than that with $1,000 \mathrm{mg} / \mathrm{kg}$ vitamin $\mathrm{E}$ or without vitamin $\mathrm{E}(\mathrm{P}<0.05)$. 

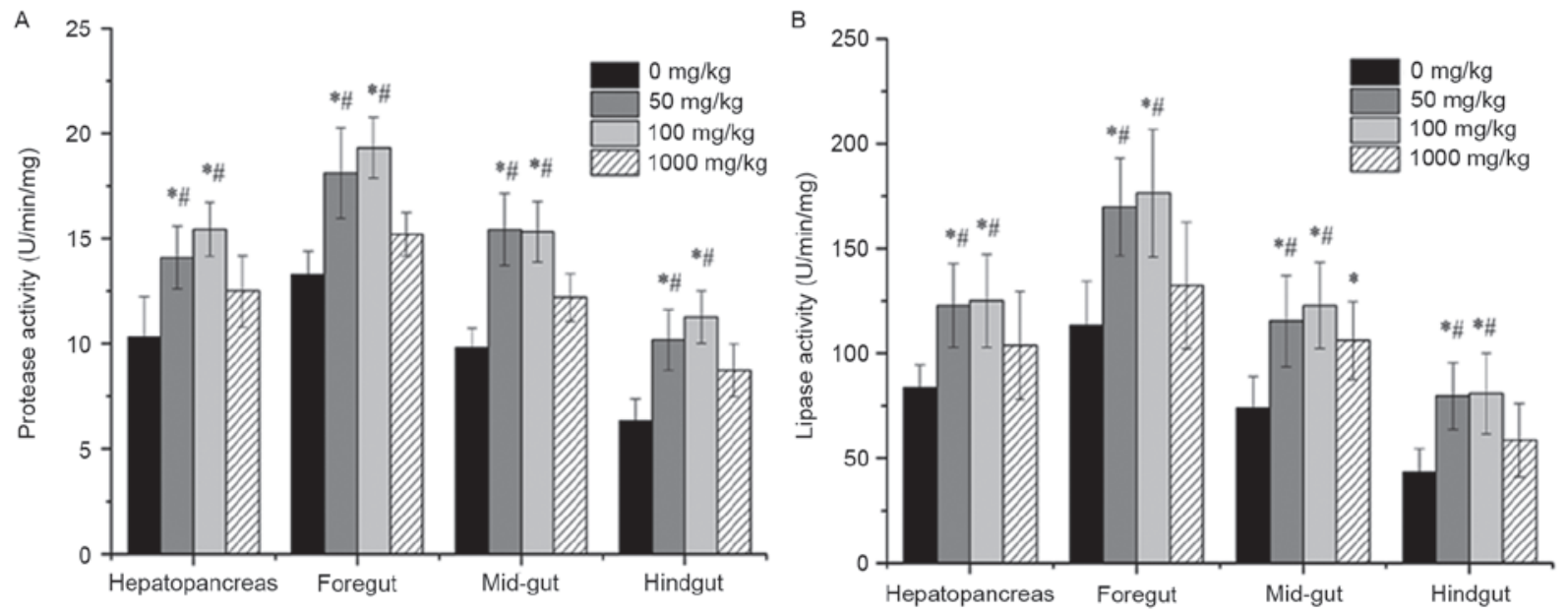

C
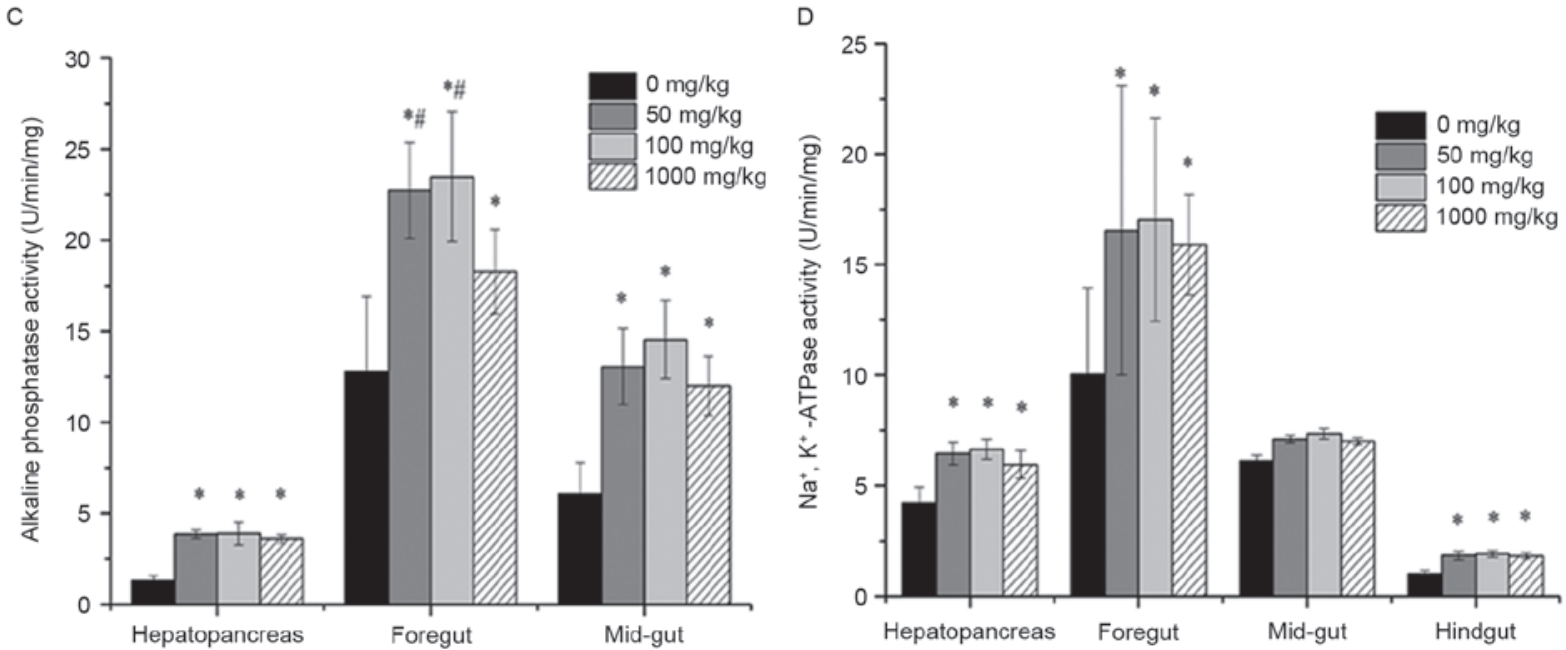

Figure 1. Digestive activity in the hepatopancreas and each segment of the gut of fish fed a diet supplemented with vitamin E: (A) Protease activity, (B) lipase activity, (C) alkaline phosphatase activity and (D) $\mathrm{Na}^{+} / \mathrm{K}^{+}$-ATPase activity. Values are expressed as the mean \pm standard deviation. " $\mathrm{P}<0.05$, compared to the group receiving $0 \mathrm{mg} / \mathrm{kg} ;{ }^{\sharp} \mathrm{P}<0.05$ compared to the group receiving $1,000 \mathrm{mg} / \mathrm{kg}$.

Effects of vitamin E supplementation on digestive enzyme activity in channel catfish. Digestive enzyme activity in the hepatopancreas and each gut segment of fish supplemented with different concentrations of vitamin $\mathrm{E}$ was shown in Fig. 1. In the hepatopancreas and all segments of the fish gut for 50 and $100 \mathrm{mg} / \mathrm{kg}$ vitamin $\mathrm{E}$ groups, protease activity was significantly increased compared to that without vitamin $\mathrm{E}$ supplementation $(\mathrm{P}<0.05)$ and that in $1,000 \mathrm{mg} / \mathrm{kg}$ group $(\mathrm{P}<0.05)$. However, there was no significant difference in the $1,000 \mathrm{mg} / \mathrm{kg}$ group compared with that of the $0 \mathrm{mg} / \mathrm{kg}$ group. Similarly, in the hepatopancreas and all segments of the fish gut for 50 and $100 \mathrm{mg} / \mathrm{kg}$ groups, lipase activity was significantly increased compared to that without vitamin $\mathrm{E}$ supplementation $(\mathrm{P}<0.05)$ and that in $1,000 \mathrm{mg} / \mathrm{kg}$ group $(\mathrm{P}<0.05)$. Additionally, there was no significant difference in the hepatopancreas, foregut and hindgut of fish in $1,000 \mathrm{mg} / \mathrm{kg}$ group compared with the $0 \mathrm{mg} / \mathrm{kg}$ group, except in the mid-gut $(\mathrm{P}<0.05)$. AKP activity was significantly increased in the hepatopancreas, foregut and mid-gut of fish in 50, 100 and $1,000 \mathrm{mg} / \mathrm{kg}$ groups compared to that without vitamin E supplementation $(\mathrm{P}<0.05) . \mathrm{Na}^{+} / \mathrm{K}^{+}$-ATPase activity was significantly increased in the hepatopancreas, foregut and hindgut of fish in 50, 100 and 1,000 mg/kg groups compared to that without vitamin $\mathrm{E}$ supplementation $(\mathrm{P}<0.05)$. However, there was no significant difference in the mid-gut of fish in 50,100 and $1,000 \mathrm{mg} / \mathrm{kg}$ groups compared with the $0 \mathrm{mg} / \mathrm{kg}$ group $(\mathrm{P}>0.05)$. In addition, the concentration of supplemented vitamin $\mathrm{E}$ influenced the digestive enzymes activity, since fish supplemented with vitamin $\mathrm{E}$ at 50 and $100 \mathrm{mg} / \mathrm{kg}$ showed obviously higher activities of protease, lipase and AKP than that without vitamin $\mathrm{E}(\mathrm{P}<0.05)$. Although the fish in $1,000 \mathrm{mg} / \mathrm{kg}$ group also exhibited increased activities, the values were lower than those in the 50 and $100 \mathrm{mg} / \mathrm{kg}$ groups.

Effects of vitamin E supplementation on gut performance of channel catfish. The results of gut weight, gut weight index, gut length as well as gut length index of fish supplemented with different concentrations of vitamin $\mathrm{E}$ are shown in Table III. Fish fed diets supplemented with vitamin E had a greater gut length and gut weight compared to those without $(\mathrm{P}<0.05)$. The gut weight index and gut length index of fish with vitamin $\mathrm{E}$ supplementation were also markedly higher than those of fish without vitamin $\mathrm{E}$ supplementation $(\mathrm{P}<0.05)$.

Effects of vitamin E supplementation on the height of intestinal folds and the thickness of the mucous membrane. The 
Table III. Effects of dietary supplementation of vitamin E on gut performance of channel catfish (Ictalurus punctatus, Rafinesque 1818).

\begin{tabular}{|c|c|c|c|c|}
\hline \multirow[b]{2}{*}{ Variable } & \multicolumn{4}{|c|}{ Vitamin E supplementation $(\mathrm{mg} / \mathrm{kg})$} \\
\hline & 0 & 50 & 100 & 1,000 \\
\hline Gut weight (g) & $0.62 \pm 0.03$ & $0.96 \pm 0.02^{\mathrm{a}}$ & $0.97 \pm 0.03^{\mathrm{a}}$ & $0.88 \pm 0.05^{\mathrm{a}}$ \\
\hline Gut weight index $(\%)$ & $0.91 \pm 0.20$ & $1.36 \pm 0.15^{\mathrm{a}}$ & $1.39 \pm 0.17^{\mathrm{a}}$ & $1.24 \pm 0.14^{\mathrm{a}}$ \\
\hline Gut length $(\mathrm{cm})$ & $15.38 \pm 0.52$ & $20.03 \pm 0.45^{\mathrm{a}}$ & $20.49 \pm 0.64^{\mathrm{a}}$ & $19.85 \pm 0.72^{\mathrm{a}}$ \\
\hline Gut length index (\%) & $82.10 \pm 4.58$ & $97.73 \pm 2.47^{\mathrm{a}}$ & $98.99 \pm 3.92^{\mathrm{a}}$ & $93.85 \pm 4.88^{a}$ \\
\hline
\end{tabular}

Values are expressed as the mean \pm standard deviation. ${ }^{\mathrm{a}} \mathrm{P}<0.05$, compared to the group receiving $0 \mathrm{mg} / \mathrm{kg}$ vitamin $\mathrm{E}$.
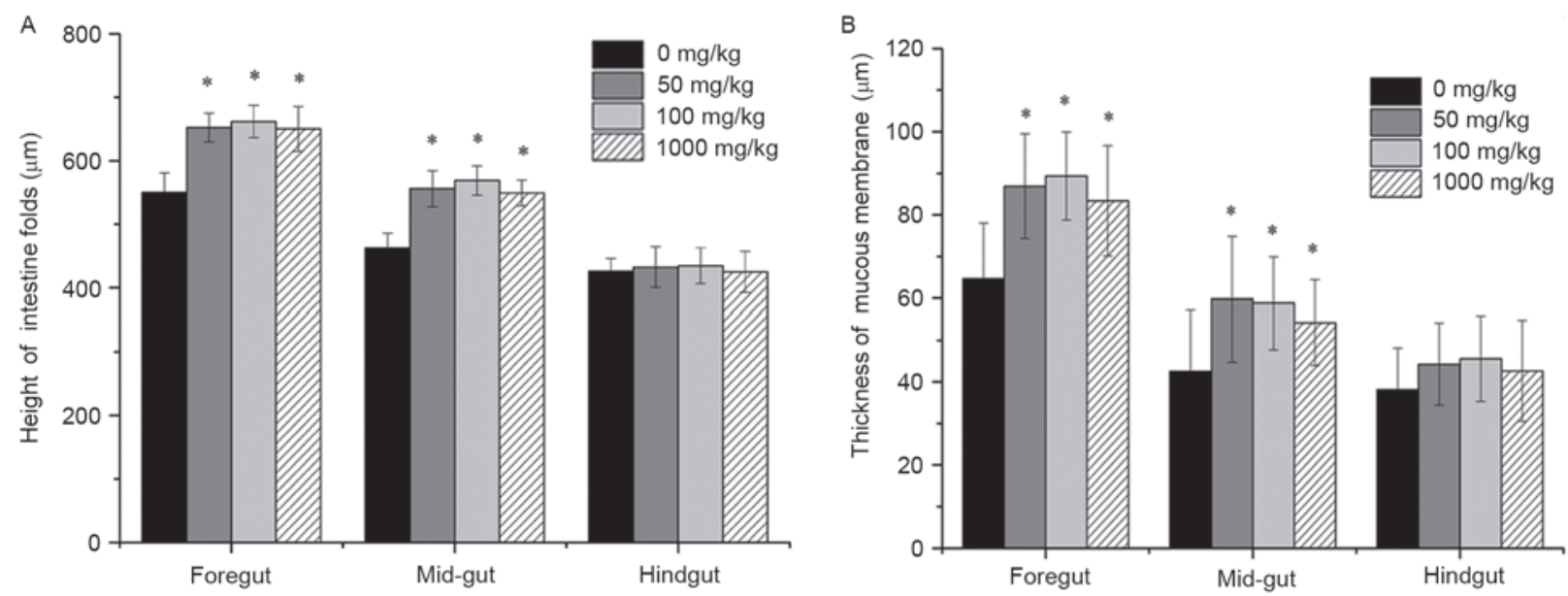

Figure 2. (A) Intestinal fold height and (B) mucous membrane thickness in each segment of gut of fish fed a diet supplemented with vitamin E. Values are expressed as the mean \pm standard deviation. " $\mathrm{P}<0.05$ compared to the group receiving $0 \mathrm{mg} / \mathrm{kg}$.

intestinal fold height and of mucous membrane thickness were observed under a microscope after H\&E staining and the statistical results are shown in Figs. 2 and 3. The intestinal folds in fish fed a diet without vitamin E showed an irregular morphology and they were small, thin and loosely arranged throughout, while they were much larger and more tightly arranged in fish fed a diet supplemented with vitamin E. Statistical analysis indicated that fished fed diets containing vitamin E had significantly larger intestinal fold height as well as a thicker mucous membrane $(\mathrm{P}<0.05)$.

Effects of vitamin E supplementation on the distribution and expression of somatostatin. Somatostatin-positive cells were observed in the foregut, mid-gut as well as hindgut. The distribution of somatostatin-positive cells in the foregut of fish fed a diet supplemented with different amounts of vitamin $\mathrm{E}$ is shown in Fig. 4A-D. Somatostatin-positive cells (brown-yellow granules) with various cellular morphologies were mainly located at the bottom of the intestinal epithelial cell layer and some of them were found between cells of the mucous epithelium. The distribution of somatostatin-positive cells among the groups in the mid- and hindgut was similar to that in the foregut (data not shown). In addition, the expression of somatostatin was evaluated by quantifying the number of somatostatin-positive cells in ten different views per section and the results for each segment of the intestine are shown in Fig. 4E. The number of somatostatin-positive cells was significantly higher in the foregut of fish with vitamin E supplementation at different concentrations compared with that in the foregut of fish without supplementation $(\mathrm{P}<0.05)$. Moreover, dietary supplementation of vitamin $\mathrm{E}$ at 100 and $50 \mathrm{mg} / \mathrm{kg}$ resulted in an obviously larger number of somatostatin-positive cells in the foregut and mid-gut of fish than that at $1,000 \mathrm{mg} / \mathrm{kg}(\mathrm{P}<0.05)$.

\section{Discussion}

The present study was performed based on a dose response design. The results indicated that the weight gain, survival rate and protein efficiency ratio of fish increased with dietary vitamin E supplementation at increasing doses of up to $100 \mathrm{mg} / \mathrm{kg}$, after which a further increase did not achieve any improvements or had a less pronounced effect. This trend was similar to that previously described in other animals (27). These results suggested that dietary supplementation with vitamin $\mathrm{E}$ is beneficial for the growth of catfish. A large body of evidence has indicated that vitamin $\mathrm{E}$ at a certain dose range promoted the growth of aquatic animals (28). Vitamin E deficiency induces excessive production of toxic lipid peroxides, leading to a decrease of weight gain and feed efficiency in animals. The addition of vitamin $\mathrm{E}$ to their diet 

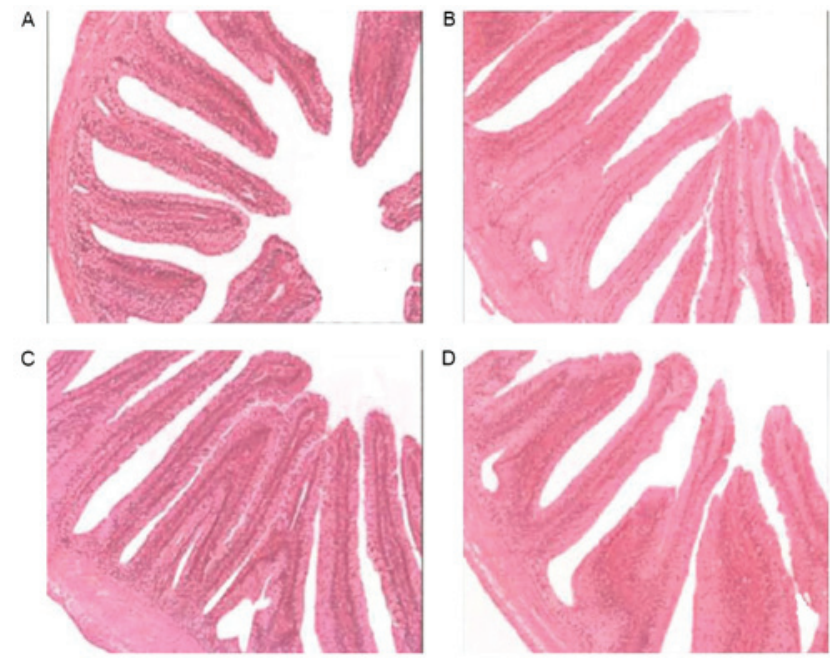

Figure 3. Morphology of intestinal folds in the foregut of fish fed a diet supplemented with vitamin E at (A) 0, (B) 50, (C) 100 and (D) 1,000 mg/kg assessed by hematoxylin and eosin staining (original magnification, $\mathrm{x} 100$ ).

prevents variable unsaturated fatty acids in diets and tissues of aquatic animals from oxidative rancidity and maintains a normal metabolism, thus increasing the survival rate, weight gain as well as feed efficiency of animals (29). In addition, dietary vitamin E supplementation decreased the feed coefficient in the present study, which has been an important and visual index to evaluate the feed quality. As previously described, adding an appropriate dose of vitamin E reduced the feed coefficient and increased the feed quality and feed efficiency $(13,14)$, and the results of the present study were consistent with this.

It is well accepted that the intestine has an important role as the site of nutrient digestion and absorption, and digestive function correlates with the development of the intestinal tract. In the present study, intestine weight and length, which reflect the development of the intestine, were significantly increased in response to high dietary vitamin E. In addition, differences in gut length and weight among fish species appear to be associated with their feeding habits as described previously (30). In the present study, dietary vitamin $\mathrm{E}$ at a certain dose range promoted gut development. Aquatic animals have a relatively simple mucosal structure. Instead of the intestinal villus as in terrestrial animals, the intestinal fold directly reflects the digestive and absorptive ability of fish $(31,32)$. Intestinal fold height has been considered as an indicator of the absorptive ability of aquatic animals. Moreover, the thickness of the mucous membrane correlates to the functional area of the intestine, directly influencing the absorption and transportation of nutrition. According to the results of the present study, dietary vitamin $\mathrm{E}$ at a certain dose range significantly increased the intestinal height and the thickness of the mucous membrane, thus improving the intestine function in catfish.

The ability of digestion is associated with the activity of digestive enzymes, which are affected by dietary intake $(33,34)$. In the present study, dietary vitamin $\mathrm{E}$ at a certain dose range increased the activities of protease and lipase. Intestinal AKP is a marker enzyme in the intestinal mucosa, which reflects epithelial cell proliferation and absorbency ability of the intestine (35). In addition, this enzyme also correlates with
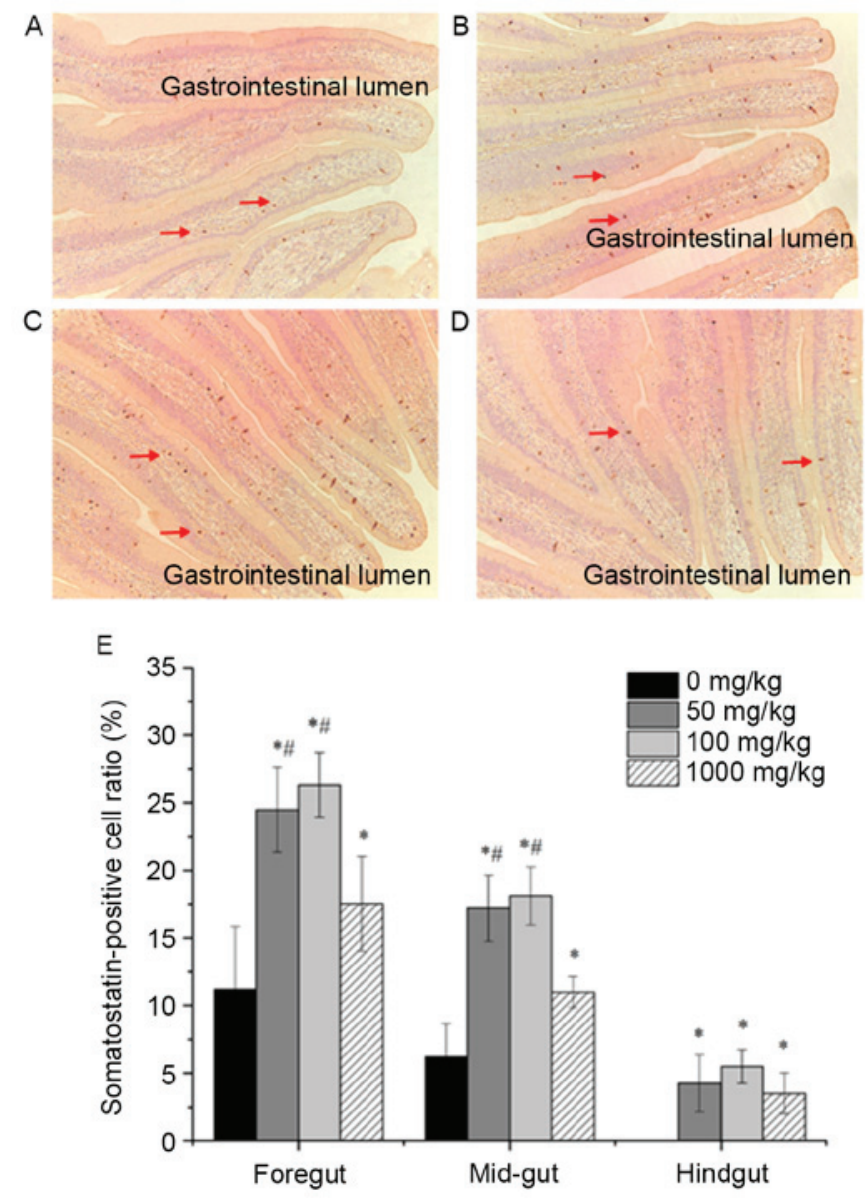

Figure 4. Distribution of somatostatin-positive cells in the foregut of fish fed a diet supplemented with vitamin E at (A) 0, (B) 50, (C) 100 and (D) $1,000 \mathrm{mg} / \mathrm{kg}$ was assessed by immunohistochemistry (original magnification, x100). Arrows indicate somatostatin-positive cells. (E) The amount of somatostatin-positive cells in each gut segment in each group. Cells were quantified in ten fields of view for each specimen. Values are expressed as the mean \pm standard deviation. ${ }^{*} \mathrm{P}<0.05$, compared to the group receiving $0 \mathrm{mg} / \mathrm{kg}$; ${ }^{\#} \mathrm{P}<0.05$, compared to the group receiving $1,000 \mathrm{mg} / \mathrm{kg}$.

the degree of differentiation of enterocytes and its content reflects their maturation status (36). In the present study, the activity of AKP was observed only in the foregut and mid-gut and was significantly higher in fish with vitamin E dietary supplementation (at a certain range dose) than in those without. In addition, the absorption of certain nutrients, including amino acids and glucose, was associated with the absorption of $\mathrm{Na}^{+}$ by $\mathrm{Na}^{+} / \mathrm{K}^{+}$-ATPase. The activity of $\mathrm{Na}^{+} / \mathrm{K}^{+}$-ATPase indirectly reflects the cell energy metabolism and function of the gut (37). As shown in the present study, vitamin E dietary supplementation at a certain dose range also increased the activity of this enzyme. Considering all of the above results, it is concluded that vitamin $\mathrm{E}$ dietary supplementation at a certain dose range significantly improved intestinal function. Furthermore, vitamin $E$ had a stimulatory effect on digestion enzyme activity in the hepatopancreas of catfish. As previously reported, enzyme secretion is closely associated with the development of the hepatopancreas (38). Dietary supplementation of vitamin E also promoted the development of the hepatopancreas.

Somatostatin is a typical brain-gut peptide of dual distribution (21,39). Somatostatin protects epithelial cells in the digestive 
tract from damage and necrosis caused by a variety of harmful substances (40). The distribution of somatostatin-positive cells in the gastrointestinal tract varied in different fish. For instance, in Korean aucha perch (Coreoperca herzi), Monopterus albus and Perca fluriatilis, somatostatin-expressing cells were only found in the stomach $(41,42)$. In Tilapia nilotca, oriental sheatfish (Silurus asotus) and mandarin fish (Siniperca chuatsi), somatostatin-expressing cells were found in the stomach and intestines (42). In the present study, somatostatin-expressing cells existed only in the intestines of channel catfish rather than in the stomach. However, channel catfish have more than two genes encoding different forms of somatostatin $(43,44)$. Different endogenous somatostatin isoforms are already known to function differently not only between tissues but also within the same target cell/tissue in the same teleost species $(45,46)$. Accordingly, further investigation of the distribution of somatostatin isoforms should also be performed. Due to the important role of somatostatin in the digestive tract, the expression of this protein may be regarded as another index to express the effects of vitamin $\mathrm{E}$ on gut function in channel catfish. According to the results of the present study, dietary supplementation of vitamin $\mathrm{E}$ at a certain dose range significantly increased the expression of somatostatin.

In conclusion, dietary vitamin E supplementation at doses within a certain range promote the growth of channel catfish and improve their intestinal structure and function. The optimal dietary vitamin E supplementation should be limited to the range of $50-100 \mathrm{mg} / \mathrm{kg}$. Due to the feasibility and efficacy of oral vitamin E supplementation for channel catfish, the present study provided an experimental foundation for the use of vitamin $\mathrm{E}$ for breeding of channel catfish in the aquaculture industry.

\section{Acknowledgements}

This study was supported by the Program for Changjiang Scholars, the Innovative Research Team in University (no. IRTO848), the Sichuan Provincial Office of Education Scientific Research Project (no. 10ZB035) and the Scientific Research Fund of Sichuan Provincial Education Department (no. 13SZA0249).

\section{References}

1. Yu W, Simmons-Menchaca M, Gapor A, Sanders BG and Kline K: Induction of apoptosis in human breast cancer cells by tocopherols and tocotrienols. Nutr Cancer 33: 26-32, 1999.

2. Blaner WS: Vitamin E: The enigmatic one! J Lipid Res 54: 2293-2294, 2013.

3. Niki E: Role of vitamin E as a lipid-soluble peroxyl radical scavenger: in vitro and in vivo evidence. Free Radic Biol Med 66: 3-12, 2014.

4. Sen CK, Khanna S and Roy S: Tocotrienols: Vitamin E beyond tocopherols. Life Sci 78: 2088-2098, 2006.

5. McDowell LR: The vitamins. Fish nutrition Academic Press, San Diego, California. Vitamin E Academic Press, London, pp93-131, 1989.

6. Halver JE: The vitamins. Fish nutrition Academic Press, San Diego, California, pp61-141, 2002.

7. Aggarwal BB, Sundaram C, Prasad S and Kannappan R: Tocotrienols, the vitamin $\mathrm{E}$ of the 21 st century: Its potential against cancer and other chronic diseases. Biochem Pharmacol 80: 1613-1631, 2010.

8. Salinthone S, Kerns AR, Tsang V and Carr DW: $\alpha$-Tocopherol (vitamin E) stimulates cyclic AMP production in human peripheral mononuclear cells and alters immune function. Mol Immunol 53: 173-178, 2013.
9. Fang Y, Zhou Y, Zhong Y, Gao X and Tan T: Effect of vitamin E on reproductive functions and anti-oxidant activity of adolescent male mice exposed to bisphenol A. Wei Sheng Yan Jiu 42: 18-22, 2013 (In Chinese).

10. Sau Sk, Paul BN, Mohanta KN and Mohanty SN: Dietary vitamin $\mathrm{E}$ requirement, fish performance and carcass composition of rohu (Labeo rohita) fry. Aquaculture 240: 359-368, 2004.

11. Thorarinsson R, Landolt ML, Elliott DG, Pascho RJ and Hardy RW: Effect of dietary vitamin E and selenium on growth, survival and the prevalence of Renibacterium salmoninarum infection in chinook salmon (Oncorhynchus tshawytscha). Aquaculture 121: 343-358, 1994.

12. Lee KJ and Dabrowski K: Interaction between vitamins $\mathrm{C}$ and $\mathrm{E}$ affects their tissue concentrations, growth, lipid oxidation, and deficiency symptoms in yellow perch (Perca flavescens). Br J Nutr 89: 589-596, 2003

13. Bai SC and Lee KJ: Different levels of dietary DL- $\alpha$-tocopheryl acetate affect the vitamin E status of juvenile Korean rockfish, Sebastes schlegeli. Aquaculture 161: 405-414, 1998.

14. Huang $\mathrm{CH}$ and Lin WY: Effects of dietary vitamin E level on growth and tissue lipid peroxidation of soft-shelled turtle, Pelodiscus sinensis (Wiegmann). Aquac Res 35: 948-954, 2004.

15. Paul B, Sarkar S and Mohanty SN: Dietary vitamin E requirement of mrigal, Cirrhinus mrigala fry. Aquaculture 242: 529-536, 2004.

16. Keenan E, Warner S, Crowe A and Courtney M: Length, Weight and Yield in Channel Catfish, Lake Diane, MI. arXiv preprint arXiv:1102.4623 2011.

17. Jobling $M$ : National Research Council (NRC): Nutrient requirements of fish and shrimp. Aquac Int 20: 601-602, 2012.

18. Gatlin DM, Bai SC and Erickson MC: Effects of dietary vitamin $\mathrm{E}$ and synthetic antioxidants on composition and storage quality of channel catfish, Ictalurus punctatus. Aquaculture 106: 323-332, 1992.

19. Bai SC and Gatlin DM: Dietary vitamin E concentration and duration of feeding affect tissue $\alpha$-tocopherol concentrations of channel catfish (Ictalurus punctatus). Aquaculture 113: 129-135, 1993.

20. Li MH, Wise DJ and Robinson EH: Effect of dietary vitamin C on weight gain, tissue ascorbate concentration, stress response and disease resistance of channel catfish ictalurus punctatus ${ }^{1}$. J World Aquac Soc 29: 1-8, 1998.

21. Patel YC: Somatostatin and its receptor family. Front Neuroendocrinol 20: 157-198, 1999.

22. Diakatou E, Kaltsas G, Tzivras M, Kanakis G, Papaliodi E and Kontogeorgos G: Somatostatin and dopamine receptor profile of gastroenteropancreatic neuroendocrine tumors: An immunohistochemical study. Endocr Pathol 22: 24-30, 2011.

23. Sheridan MA and Hagemeister AL: Somatostatin and somatostatin receptors in fish growth. Gen Comp Endocrinol 167: 360-365, 2010.

24. Council NR: Nutrient requirements of fish. Washington: National Academy, 1993.

25. Wen J, Morrissey PA, Buckley DJ and Pja S: Supranutritional vitamin E supplementation in pigs: Influence on subcellular deposition of $\alpha$-tocopherol and on oxidative stability by conventional and derivative spectrophotometry. Meat Science 47: 301-310, 1997.

26. Kühlwein H, Merrifield DL, Rawling MD, Foey AD and Davies SJ: Effects of dietary $\beta-(1,3)(1,6)-D$-glucan supplementation on growth performance, intestinal morphology and haemato-immunological profile of mirror carp (Cyprinus carpio L.). J Anim Physiol Anim Nutr 98: 279-289, 2014.

27. Falahatkar B, Amlashi AS and Conte F: Effect of dietary vitamin $\mathrm{E}$ on cortisol and glucose responses to handling stress in juvenile beluga Huso huso. J Aquat Anim Health 24: 11-16, 2012.

28. Taveekijakarn P, Miyazaki T, Matsumoto M and Arai S: Study on vitamin E deficiency in amago salmon. Bull Fac Biores Mie Univ 16, 17-24, 1996.

29. Wassef E, El Masry MH and Mikhail FR: Growth enhancement and muscle structure of striped mullet, Mugil cephalus L., fingerlings by feeding algal meal-based diets. Aquac Res 32: 315-322, 2001.

30. De Silva SS and Anderson TA: Fish nutrition in aquaculture. Springer Science Business Media, 1994.

31. Olli JJ and Krogdahi A: Nutritive value of four soybean products as protein sources in diets for rainbow trout (Oncorhynchus mykiss, Walbaum) reared in fresh water. Acta Agric Scand A Anim Sci 44: 185-192, 1994. 
32. Farhangi $\mathrm{M}$ and Carter CG: Growth, physiological and immunological responses of rainbow trout (Oncorhynchus mykiss) to different dietary inclusion levels of dehulled lupin (Lupinus angustifolius). Aquac Res 32: 329-340, 2001.

33. Galgani F and Ceccaldi HJ: Effet de l'incorporation de farines de soja et de poisson dans l'aliment sur la croissance et les enzymes digestives de Penaeus vannamei. Aquat Living Resour 1: 181-187, 1988. (In French)

34. Kumlu M and Jones D: The effect of live and artificial diets on growth, survival and trypsin activity in larvae of Penaeus indicus. J World Aquac Soc 26: 406-415, 1995.

35. Cuvier-Péres A and Kestemont P: Development of some digestive enzymes in Eurasian perch larvae Perca fluviatilis. Fish Physiol Biochem 24: 279-285, 2001.

36. Wood SR, Zhao Q, Smith LH and Daniels CK: Altered morphology in cultured rat intestinal epithelial IEC-6 cells is associated with alkaline phosphatase expression. Tissue Cell 35: 47-58, 2003

37. Rhoads JM, Chen W, Chu P, Berschneider HM, Argenzio RA and Paradiso AM: L-glutamine and L-asparagine stimulate $\mathrm{Na}^{+}-\mathrm{H}^{+}$ exchange in porcine jejunal enterocytes. Am J Physiol 266: G828-G838, 1994.

38. Yan L and Qiu-Zhou X: Dietary glutamine supplementation improves structure and function of intestine of juvenile Jian carp (Cyprinus carpio var. Jian). Aquaculture 256: 389-394, 2006.
39. Lin $X$ and Peter RE: Somatostatins and their receptors in fish. Comp Biochem Physiol B Biochem Mol Biol 129: 543-550, 2001.

40. Reichlin S: Somatostatin. N Engl J Med 309: 1495-1501, 1983.

41. Lee JH, Ku SK, Park KD and Lee HS: Immunohistochemical study of the gastrointestinal endocrine cells in the Korean aucha perch. J Fish Biol 65: 170-181, 2004.

42. Pan QS, Fang ZP and Huang FJ: Identification, localization and morphology of APUD cells in gastroenteropancreatic system of stomach-containing teleosts. World J Gastroenterol 6: 842-847, 2000.

43. Hobart P, Crawford R, Shen L, Pictet R and Rutter WJ: Cloning and sequence analysis of cDNAs encoding two distinct somatostatin precursors found in the endocrine pancreas of anglerfish. Nature 288: 137-141, 1980.

44. Moore CA, Kittilson JD, Ehrman MM and Sheridan MA: Rainbow trout (Oncorhynchus mykiss) possess two somatostatin mRNAs that are differentially expressed. Am J Physiol 277: R1553-R1561, 1999.

45. Hanssen L, Hanssen KF and Myren J: Inhibition of secretin release and pancreatic bicarbonate secretion by somatostatin infusion in man. Scand J Gastroenterol 12: 391-394, 1977.

46. Dollinger HC, Raptis S and Pfeiffer EF: Effects of somatostatin on exocrine and endocrine pancreatic function stimulated by intestinal hormones in man. Horm Metab Res 8: 74-78, 1976. 